\title{
Relationship between renal function and circulating microparticles, soluble P-selectin and E-selectin levels in atrial fibrillation
}

\author{
Yee Cheng Lau ${ }^{1} \cdot$ Qinmei Xiong $^{1,2} \cdot$ Andrew D. Blann $^{1} \cdot$ Gregory Y. H. Lip $^{1}$
}

Published online: 26 September 2016

(C) The Author(s) 2016. This article is published with open access at Springerlink.com

\begin{abstract}
Atrial fibrillation (AF) and chronic kidney disease are closely related, and any associated risk of stroke and thromboembolism due to AF is increased by concurrent renal dysfunction. The mechanism(s) for this include abnormalities in platelets and endothelial cells. We hypothesized relationships between levels of circulating platelet microparticles (PMPs, defined by CD42b), soluble P selectin (both reflecting platelet activation), soluble E-selectin (reflecting endothelial activation) and endothelial/platelet microparticles (EPMPs, defined by CD31) with progressive renal dysfunction. Blood samples were obtained from 160 anticoagulated AF patients. Microparticles were measured by flow cytometry, soluble $\mathrm{E}$ and $\mathrm{P}$ selectin levels by ELISA. Renal function was determined by estimated glomerular filtration rate (eGFR). EPMP levels demonstrated a linear increased trend across quartiles of eGFR $(p=0.034)$ and CKD stage $(p<0.001)$, and correlated with eGFR and serum creatinine $(p<0.01)$. PMPs, P-selectin and E-selectin levels were not significantly different across groupings of renal dysfunction, and no significant correlations with eGFR were evident $(\mathrm{p}=0.186, \mathrm{p}=0.561$, $\mathrm{p}=0.746$ respectively). Stepwise multivariable regression analysis demonstrated that worsening renal function was an independent predictor of EPMP levels $(p<0.001)$. In wellanticoagulated $\mathrm{AF}$ patients, there is potential relationship
\end{abstract}

Dr. Lau and Dr. Xiong contributed equally to this project.

Gregory Y. H. Lip

g.y.h.lip@bham.ac.uk

1 University of Birmingham Institute of Cardiovascular Science, City Hospital, Dudley Road, Birmingham, UK

2 Cardiovascular Department, The Second Affiliated Hospital of Nanchang University, Nanchang, China between endothelial function (as judged by elevated EPMP levels, with no change in PMPs) and renal function. Other markers of prothombotic state or cellular activation (PMP, P-selectin and E-selectin levels) were not significantly different across the various degree of renal dysfunction. Renal function must be addressed when measuring EPMP levels.

Keywords Atrial fibrillation - Chronic renal disease · Microparticles · Soluble P selectin · Soluble E selectin

\section{Introduction}

Non-valvular atrial fibrillation (AF) is associated with an elevated risk of ischaemic stroke and systemic thromboembolism [1,2]. This risk is further increased by concurrent diagnosis of chronic kidney disease (CKD) or end-stage renal disease (ESRD) and results in a worse clinical outcome in terms of cardiovascular disease [3-5]. The precise mechanism(s) underlying the worse outcomes in AF patients with CKD and ESRD are incompletely understood and so require further investigation. One such aspect is circulating microparticles, known to be increased in dialysis dependent ESRD [6]. These microparticles are heterogenous vesicles, derived from cellular membrane where the parent cells have undergone necrosis, injury, apoptosis or activation $[7,8]$. Depending on the nature of their parent cells (such as leukocytes, platelets and endothelial cells), different microparticles subsets possess a unique composition and content, which vary in their thrombotic potentials [9-11]. Thus, different microparticles subsets can not only mark pathology of their parent cells, but may also influence coagulation by directly facilitating formation of coagulation complexes or via modulation of tissue factor dependent pathways $[12,13]$. 
Although microparticles levels are increased in ESRD and are linked to increased cardiovascular mortality $[6,14]$, a contradictory relationship exists between AF and levels of circulating microparticles $[15,16]$. A potential relationship between worsening degrees of non-dialysis dependent renal dysfunction and microparticles amongst AF patients, as well as the subsequent effect on levels of various microparticle subsets, has yet to be investigated.

In this study, we hypothesised that, in patients at risk of a thrombotic events (that is, with AF) levels of platelet microparticles and/or endothelial/platelet microparticles would be associated inversely with renal function, as defined by the estimated glomerular filtration rate. To provide perspective for the microparticle aspect, we also measured levels of two plasma markers of platelet and endothelial biology, these being soluble $\mathrm{P}$ selectin and soluble E selectin respectively, both known to be abnormal in cardiovascular disease $[17,18]$.

\section{Patients and methods}

\section{Subjects}

All 160 subjects with non-valvular AF were recruited from routine out-patient clinics, and all had been taking oral anticoagulation (warfarin) for at least 12 weeks. Doseadjustment for warfarin was done in specialised scientistled anticoagulation clinics, achieving a stable international normalised ratio (INR) between two and three. INR was again determined on the day of testing to assess effective anticoagulation.

Exclusion criteria were age $<18$ years, diagnosis of valvular AF (severe rheumatic stenosis, metallic prosthetic valve, $\mathrm{mitral} /$ tricuspid ring repair), active or recent ( $<12$ months) malignancy, active immunological disease, chronic liver disease, recent or chronic infections, chronic inflammatory disease, connective tissue disease, recent stroke/acute coronary syndrome (within 2 months), active bleeding, recent arterial/venous thrombosis or recent surgery, known haemophilia or thrombophilia (such as Factor V Leiden, Protein $\mathrm{C} / \mathrm{S} /$ anti-thrombin deficiency, anti-phospholipid syndrome), use of an anti-platelet agent other than aspirin, and use of an oral anticoagulant other than warfarin. Standard clinical and demographic data were obtained.

A routine blood test was taken for to assess for renal function (urea, creatinine and electrolytes), with subsequent calculation of estimated glomerular filtration rate (eGFR) [19]. To aid clarity, patients with CKD stages four and five were merged into a single group [20]. In accordance with the Declaration of Helsinki, the project was approved by the Local Research Ethics Committee and written informed consent was obtained from each subject. Data were anonymised prior to statistical analysis.

\section{Laboratory methods}

Blood samples were collected from a large antecubital vein using a 21-gauge needle directly into Vacutainer ${ }^{\circledR}$ tubes (Becton Dickinson, UK) containing $0.5 \mathrm{ml} \mathrm{3.2 \%} \mathrm{sodium}$ citrate. For microparticle detection, platelet-poor plasma (PPP) was obtained after 15 min centrifugation of citrated blood at $2800 \mathrm{~g}$ and further centrifugation of PPP at $13,000 \mathrm{~g}$ for 2 min to remove residual cellular fragments to obtain platelet-free plasma (PFP) as per ISTH guidelines [20]. Aliquots of the plasmas were frozen at $-70^{\circ} \mathrm{C}$ for subsequent batch analysis and so had undergone a single-freeze thaw cycle.

PFP was initially incubated separately for $30 \mathrm{~min}$ with $0.5 \mu \mathrm{g}$ of biotinylated anti-human CD42b antibody (Abcam, Cambridge, UK) for platelet-derived microparticles (PMP), or $0.5 \mu \mathrm{g}$ of biotinylated anti-human antibody to CD31 (PECAM, present on both platelets and endothelial cells) (Abcam, Cambridge, UK) for mixed endothelial-derived microparticles (EPMPs). This was followed by a second incubation with $0.25 \mu \mathrm{g}$ of Streptavidin-Alexa Fluor-647 nm-RPhycoerythrin conjugate (Life Technology, Paisley, UK) for $30 \mathrm{~min}$ and then diluted with $990 \mu \mathrm{l}$ filtered PBS (final dilution 1:100). MP analysis was promptly performed using the Apogee A50 flow cytometer (Apogee Flow Systems, High Wycombe, UK). Polystyrene beads of 110, 200, $500 \mathrm{~nm}$ and $1 \mu \mathrm{m}$ diameter (Apogee Flow Systems) were used to set up the MP-size gate and small-size MP defined as events with size between 110 and $500 \mathrm{~nm}$. Detailed instruction regarding gating selection has previously been described [21]. For enzyme-linked immunosorbent assay (ELISA) blood samples were centrifuged within $30 \mathrm{~min}$ from collection at $1500 \mathrm{~g}$ for $20 \mathrm{~min}$ at $4^{\circ} \mathrm{C}$. The resultant plasma was then collected and stored at $-70^{\circ} \mathrm{C}$ until later batch processing by ELISA to measure soluble E-selectin and soluble P-selectin (R\&D Systems, Abingdon, UK).

\section{Statistical analysis}

Continuously variable data are expressed as mean and standard deviation (SD) or median and interquartile range (IQR) dependent on distribution. To demonstrate a step change in research indices, data were grouped by quartile of eGFR and also by the clinical tool of CKD stage, that being Stage 1 (eGFR $\geq 90 \mathrm{ml} / \mathrm{min} / 1.73 \mathrm{~m}^{2}$ ), Stage 2 (eGFR 60-89), Stage 3 (eGFR 30-59) and Stage 4/5 combined (eGFR $\leq 29$ ) [22]. When the groups are ordered it is not reasonable to compared each pair of groups with each other (as in an analysis of variance of groups that are independent), but instead consideration should be given whether there is a linear trend across the four groups. This was sought according to methods described by Altman [23]. However, as the eGFR has a natural continuous variation, correlations were also sought 
Table 1 Clinical and demographic data

\begin{tabular}{|c|c|c|c|c|c|}
\hline & \multicolumn{4}{|l|}{ eGFR } & \multirow{2}{*}{$\begin{array}{l}\text { P for } \\
\text { linear } \\
\text { trend }\end{array}$} \\
\hline & $\begin{array}{l}\text { Quartile 1: best } \\
\text { renal function }\end{array}$ & Quartile 2 & Quartile 3 & $\begin{array}{l}\text { Quartile 4: } \\
\text { worst renal } \\
\text { function }\end{array}$ & \\
\hline $\begin{array}{l}\text { eGFR (ml/ } \\
\min / 1.73)\end{array}$ & $87(5)$ & $70(3)$ & $56(6)$ & $30(7)$ & $<0.001$ \\
\hline Age (years) & $68(12)$ & $74.5(8)$ & $74(7)$ & $80(8)$ & $<0.001$ \\
\hline $\operatorname{Sex}(m / f)$ & $24 / 16$ & $21 / 19$ & $22 / 18$ & $21 / 19$ & 0.895 \\
\hline $\begin{array}{l}\text { Race (non-black/ } \\
\text { black) }\end{array}$ & $37 / 3$ & $39 / 1$ & $33 / 7$ & $35 / 5$ & 0.135 \\
\hline Weight (kg) & $92(24)$ & $87(22)$ & $83.5(15)$ & $76(21)$ & $<0.001$ \\
\hline Creatinine $(\mu \mathrm{mol} / 1)$ & $70(13)$ & $85(14)$ & $109(25)$ & $166(60)$ & $<0.001$ \\
\hline INR & $2.6(0.8)$ & $2.6(0.7)$ & $2.5(0.8)$ & $2.4(0.6)$ & 0.086 \\
\hline $\mathrm{SBP}(\mathrm{mmHg})$ & $132(18)$ & $135(17)$ & $126(24)$ & $129(18)$ & 0.096 \\
\hline DBP (mmHg) & $76(13)$ & $75(12)$ & $72(13)$ & $69(9)$ & 0.002 \\
\hline BMI $\left(\mathrm{kg} / \mathrm{m}^{2}\right)$ & $30.3(6.3)$ & $31.0(5.6)$ & $29.5(4.6)$ & $28.1(6.8)$ & 0.027 \\
\hline \multicolumn{6}{|c|}{ Co-morbidities (yes/no) } \\
\hline $\begin{array}{l}\text { Ischaemic heart } \\
\text { disease }\end{array}$ & $12 / 28$ & $15 / 25$ & $16 / 24$ & $23 / 17$ & 0.082 \\
\hline $\begin{array}{l}\text { Type } 2 \text { diabetes } \\
\text { mellitus }\end{array}$ & $14 / 26$ & $11 / 29$ & $17 / 23$ & $24 / 16$ & 0.022 \\
\hline Hypertension & $33 / 7$ & $34 / 6$ & $33 / 7$ & $35 / 5$ & 0.914 \\
\hline Heart failure & $12 / 28$ & $12 / 28$ & $15 / 25$ & $21 / 19$ & 0.124 \\
\hline COPD & $9 / 31$ & $4 / 36$ & $5 / 35$ & $9 / 31$ & 0.296 \\
\hline $\begin{array}{l}\text { Concurrent } \\
\text { antiplatelet }\end{array}$ & $2 / 38$ & $2 / 38$ & $4 / 36$ & $4 / 36$ & 0.696 \\
\hline Current smoker & $2 / 38$ & $1 / 39$ & $1 / 39$ & $2 / 38$ & 0.875 \\
\hline $\begin{array}{l}\text { CKD stage } \\
1 / 2 / 3 / 4 \text { (n) }\end{array}$ & $23 / 17 / 0 / 0$ & $0 / 40 / 0 / 0$ & $0 / 12 / 28 / 0$ & $0 / 0 / 17 / 23$ & $<0.001$ \\
\hline $\begin{array}{l}\text { Median (IQR) } \\
\text { CKD stage }\end{array}$ & $1(1-2)$ & $2(2-2)$ & $3(2-3)$ & $4(3-4)$ & $<0.001$ \\
\hline
\end{tabular}

Data mean (standard deviation), number of subjects, or median and inter-quartile range (CKD stage)

eGFR estimated glomerular filtration rate, INR international normalised ratio, $S B P$ systolic blood pressure, $D B P$ diastolic blood pressure, $B M I$ body mass index using Spearman's method. Categorical indices were analysed by the Chi squared test. Stepwise regression analyses were performed to determine independent influences on research indices. All analyses were performed on Minitab 17 , and $\mathrm{p}<0.05$ was considered as significant.

\section{Results}

Clinical and demographic details of the 160 AF patients sorted by quartile of eGFR are shown in Table 1 . There were no significant differences in INR, gender, most comorbidities, race (black vs. non-black), systolic blood pressure, nicotine use or concurrent antiplatelet use. As expected, there was worsening renal function with increasing CKD stage, age and creatinine level, but diastolic blood pressure and BMI were lowest in those with worse renal function. Diabetes was linked to worsening renal function.
EPMP levels increased sequentially across the quartiles of worsening renal function as defined by eGFR, but there were no differences in PMP, soluble P-selectin, or E-selectin levels (Table 2). The trend in EPMP across CKD stages $1-4 / 5$ of 8.62 (3.94-18.23), 6.12 (1.62-12.78), 9.21 (1.82$23.17)$ and $21.05(3.1-46.47) \times 10^{3} / \mu 1$ respectively, although not completely linear, was nonetheless highly significant $(\mathrm{p}<0.001)$.

There was a significant negative correlation between eGFR and EPMP, and a positive correlation between serum creatinine and EPMP $(r=0.209, p=0.008)$ (Table 3). There were no significant correlations between eGFR and PMP, soluble P-selectin or soluble E-selectin levels. Using stepwise regression analysis of indices in Table 1 with $p<0.05$, the only independent predictor EPMP was the eGFR $(p<0.001)$. Other demographic factors and comorbidities did not have any significant impact on EPMP levels. 
Table 2 Microparticles, soluble P-selectin and soluble E-selectin levels according to quartiles of eGFR

\begin{tabular}{|c|c|c|c|c|c|}
\hline & \multicolumn{4}{|l|}{ eGFR } & \multirow{2}{*}{$\begin{array}{l}\mathrm{P} \text { for } \\
\text { linear } \\
\text { trend }\end{array}$} \\
\hline & Quartile 1 & Quartile 2 & Quartile 3 & Quartile 4 & \\
\hline PMPs events/ $\mu 1$ & $281(134-1348)$ & $2123(324-4079)$ & $1476(82-5041)$ & $209(29-2043)$ & 0.897 \\
\hline $\begin{array}{l}\text { EPMPs } \\
\text { events } / 10^{3} / \mu 1\end{array}$ & $5.18(0.74-12.35)$ & $6.52(4.22-11.67)$ & $6.09(0.41-24.45)$ & $\begin{array}{l}21.05 \\
(6.43-29.71)\end{array}$ & 0.034 \\
\hline $\begin{array}{l}\text { Soluble P selectin } \\
(\mathrm{ng} / \mathrm{ml})\end{array}$ & $9.1(7.3-11.0)$ & $9.0(7.6-10.4)$ & $9.1(7.2-11.4)$ & $8.3(6.2-10.8)$ & 0.368 \\
\hline $\begin{array}{l}\text { Soluble E selectin } \\
\text { (ng/ml) }\end{array}$ & $39(29-105)$ & $39(27-74)$ & $43(29-63)$ & $39(26-45)$ & 0.930 \\
\hline
\end{tabular}

Data presented as median and IQR

PMPs platelet microparticles, EPMPs endothelial/platelet microparticles
Table 3 Spearman correlations of the eGFR with microparticles, P-selectin and E-selectin levels

\begin{tabular}{lrr}
\hline & \multicolumn{1}{c}{$\mathrm{r}_{\mathrm{s}}$} & \multicolumn{1}{c}{$\mathrm{p}$} \\
\hline Platelet microparticles & 0.095 & 0.234 \\
Endothelial/platelet microparticles & -0.319 & $<0.001$ \\
Soluble P selectin & 0.086 & 0.279 \\
Soluble E selectin & 0.133 & 0.094 \\
\hline
\end{tabular}

$r_{s}$ Spearman's correlation coefficient

\section{Discussion}

Renal function is an emerging additional risk factor for cardiovascular disease [24]. As AF and CKD are closely linked, there is a strong need to identify potential markers that enable assessment of the decline of renal function and alteration(s) of thrombotic potential [1-5]. We demonstrate that among AF patients receiving oral anticoagulation, progressive worsening of renal function is associated with a linear trend of increasing levels of EPMP. Reduced diastolic blood pressure in patients with greatest renal dysfunction may be due to the higher proportion of patient with ischaemic heart disease and the likelihood that they will be more intensively treated. Similarly, the increasing frequency of diabetes across the groups is very likely to be due to diabetic nephropathy. Nevertheless, neither of these factors were selected on multivariate analysis and renal function emerged as the only independent determinant of EPMP levels.

Our current finding confirms previous studies finding increased microparticles in renal dysfunction/failure $[6,25$, 26]. However, our data contrasts with the lack of positive findings in other studies, possible because of the use of different antibodies, such as to CD144, CD146 and CD41 [26], annexin-V [27] and/or to CD69E [28], and so defining different species of MP [8], in demographic and co-morbidities (the approximate mean age of the patients of Fauvre et al. [26] is 59 years, of Lu et al. [28] is 47 years, of Chen et al. [27] it is 70 years, whilst in our patients it is 74 years), racial background ( $90 \%$ of our patients were of European descent whilst we presume the majority of those of Chen et al. and Lu et al. were from the Far East), and differences in ELISA reagents.

As EPMPs may arise from endothelial cells and platelets in response to damage/activation, increased levels may reflect pathology of either or both parent cells. We used CD31, also known as PECAM, is found on the surface of both platelets and endothelial cells [29-32]. However, the failure of 'pure' PMPs to associate with any renal function index provide support for the hypothesis that EPMPs are more likely to reflect endothelial pathology [33]. The presence of greater vascular and endothelial injury associated with (or as a result of) progressive renal dysfunction will cause alteration to EMP levels. Hence, this study also extends previous work by demonstrating a progressive, step-wise, increase in EPMP levels among those with worsening degrees of renal failure. Nevertheless, elevated CD31/ annexin-V EPMP levels are present in acute coronary syndromes, may be a surrogate of cellular injury due to cardiovascular risk diseases, and correlate with cardiovascular outcomes [34-36], but this can be accounted for in our study by the similar comorbidities.

Our study demonstrates the lack of significant change in PMP levels in relation with worsening renal function among AF patients. Previous studies [15, 37] have shown that PMP levels are affected less by arrhythmia and more to underlying cardiovascular diseases. Lu et al. [28] also found that CD41-defined PMPs and soluble P selectin were progressively lower in those with the worse CKD, in contrast to our data which found no such relationship. The lack of alterations in soluble P-selectin and E-selectin levels across subjects with worsening renal function suggests that these biomarkers of platelet and endothelial cell activation may be less affected by renal (dys)function.

Limitations of our study include lack of data regarding the potential roles of other microparticles besides PMP and EPMP, such as 'pure' endothelial (e.g. as defined by CD62E, CD144, CD146, etc. [8, 26, 38]), or leukocyte subsets. Furthermore, all patients were taking warfarin, so that extrapolation of non-AF and/or non-anticoagulated groups 
may be difficult, and without a platelet count we cannot relate this index to PMPs or soluble P selectin. However, we have previously been unable to link soluble $P$ selectin with platelet count $[39,40]$. Further studies should be performed to investigate their potential involvement in the relationship of progressive renal dysfunction and AF.

In conclusion, among well-anticoagulated AF patients, there is relationship between endothelial function (as judged by EPMPs) and renal function. Other markers of prothombotic state or cellular activation, such as PMP, P-selectin and E-selectin levels were not significantly different across the various degree of renal dysfunction.

\section{Compliance with ethical standards}

Conflicts of interest Dr. Blann: research funding from Boehringer Ingelheim, Daiichi-Sankyo, Speaker for Bayer, BMS/Pfizer and Boehringer Ingelheim. Professor Lip: consultant for Bayer/Jensen J\&J, Astellas, Merck, Sanofi, BMS/Pfizer, Biotronik, Medtronic, Portola, Boehringer Ingelheim, Microlife and Daiichi-Sankyo. Speaker for Bayer, BMS/Pfizer, Medtronic, Boehringer Ingelheim, Microlife, Roche and Daiichi-Sankyo.

Open Access This article is distributed under the terms of the Creative Commons Attribution 4.0 International License (http://creativecommons.org/licenses/by/4.0/), which permits unrestricted use, distribution, and reproduction in any medium, provided you give appropriate credit to the original author(s) and the source, provide a link to the Creative Commons license, and indicate if changes were made.

\section{References}

1. Wolf PA, Dawber TR, Thomas HE Jr, Kannel WB (1978) Epidemiologic assessment of chronic atrial fibrillation and risk of stroke: the Framingham study. Neurology 28(10):973-977

2. Yamashita Y, Hamatani Y, Esato M, Chun YH, Tsuji H, Wada H et al (2016) Clinical characteristics and outcomes in extreme elderly (age $\geq 85$ ) Japanese patients with atrial fibrillation: the Fushimi AF registry. Chest 149(2):401-412

3. Go AS, Fang MC, Udaltsova N, Chang Y, Pomernacki NK, Borowsky L et al (2009) Impact of proteinuria and glomerular filtration rate on risk of thromboembolism in atrial fibrillation: the anticoagulation and risk factors in atrial fibrillation (ATRIA) study. Circulation 119(10):1363-1369

4. Olesen JB, Lip GY, Kamper AL, Hommel K, Kober L, Lane DA et al (2012) Stroke and bleeding in atrial fibrillation with chronic kidney disease. New Engl J Med 367:625-635

5. Bonde AN, Lip GY, Kamper AL, Hansen PR, Lamberts M, Hommel K et al (2014) Net clinical benefit of antithrombotic therapy in patients with atrial fibrillation and chronic kidney disease: a nationwide observational cohort study. J Am Coll Cardiol 64:2471-2482

6. Amabile N, Guerin AP, Leroyer A, Mallat Z, Nguyen C, Boddaert $\mathrm{J}$ et al (2005) Circulating endothelial microparticles are associated with vascular dysfunction in patients with end-stage renal failure. J Am Soc Nephrol 16(11):3381-3388

7. Shantsila E, Montoro-Garcia S, Gallego P, Lip GY (2014) Circulating microparticles: challenges and perspectives of flow cytometric assessment. Thromb Haemostasis 111(6):1009-1014
8. Nomura S (2016) Microparticle and atherothrombotic diseases. J Atheroscler Thromb 23(1):1-9

9. Sinauridze EI, Kireev DA, Popenko NY, Pichugin AV, Panteleev MA, Krymskaya OV et al (2007) Platelet microparticle membranes have 50 - to 100 -fold higher specific procoagulant activity than activated platelets. Thromb Hemostasis 97(3):425-434

10. Jy W, Jimenez JJ, Mauro LM, Horstman LL, Cheng P, Ahn ER et al (2005) Endothelial microparticles induce formation of platelet aggregates via a von Willebrand factor/ristocetin dependent pathway, rendering them resistant to dissociation. J Thromb Haemostasis 3(6):1301-1308

11. Falati S, Liu Q, Gross P, Merrill-Skoloff G, Chou J, Vandendries E et al (2003) Accumulation of tissue factor into developing thrombi in vivo is dependent upon microparticle P-selectin glycoprotein ligand 1 and platelet P-selectin. J Exp Med 197(11):1585-1598

12. Del Conde I, Shrimpton CN, Thiagarajan P, Lopez JA (2005) Tissue-factor-bearing microvesicles arise from lipid rafts and fuse with activated platelets to initiate coagulation. Blood 106(5):1604-1611

13. Steppich B, Mattisek C, Sobczyk D, Kastrati A, Schomig A, Ott I (2005) Tissue factor pathway inhibitor on circulating microparticles in acute myocardial infarction. Thromb Haemostasis 93(1):35-39

14. Amabile N, Guerin AP, Tedgui A, Boulanger CM, London GM (2012) Predictive value of circulating endothelial microparticles for cardiovascular mortality in end-stage renal failure: a pilot study. Nephrol Dialysis Transplant 27(5):1873-1880

15. Choudhury A, Chung I, Blann AD, Lip GY (2007) Elevated platelet microparticle levels in nonvalvular atrial fibrillation: relationship to $\mathrm{P}$-selectin and antithrombotic therapy. Chest 131(3):809-815

16. Jesel L, Abbas M, Toti F, Cohen A, Arentz T, Morel O (2013) Microparticles in atrial fibrillation: a link between cell activation or apoptosis, tissue remodelling and thrombogenicity. Int J Cardiol 168(2):660-669

17. Blann AD, Nadar SK, Lip GY (2003) The adhesion molecule P-selectin and cardiovascular disease. Eur Heart J 24:2166-2179

18. Roldán V, Marín F, Lip GY, Blann AD (2003) Soluble E-selectin in cardiovascular disease and its risk factors. A review of the literature. Thromb Haemost 90:1007-1020

19. Levey AS, Bosch JP, Lewis JB, Greene T, Rogers N, Roth D (1999) A more accurate method to estimate glomerular filtration rate from serum creatinine: a new prediction equation. Modification of diet in renal disease study group. Ann Intern Med $130: 461-470$

20. Lacroix R, Judicone C, Poncelet P, Robert S, Arnaud L, Sampol $J$ et al (2012) Impact of pre-analytical parameters on the measurement of circulating microparticles: towards standardization of protocol. J Thromb Haemost 10(3):437-446

21. Kidney Disease Improving global outcomes (KDIGO) CKD Work Group (2013) KDIGO 2012 clinical practice guideline for the evaluation and management of chronic kidney disease. Kidney Int (Suppl 3): 1-150

22. Montoro-Garcia S, Shantsila E, Orenes-Pinero E, Lozano ML, Lip GY (2012) An innovative flow cytometric approach for small-size platelet microparticles: influence of calcium. Thromb Haemostasis 108(2):373-383

23. Altman DG (1991) Practical statistics for medical research. Chapman \& Hall, London

24. Kundhal K, Lok CE (2005) Clinical epidemiology of cardiovascular disease in chronic kidney disease. Nephron Clin Pract $101: c 47-52$

25. Almquist T, Mobarrez F, Jacobson SH, Wallen H, Hjemdahl $P$ (2016) Effects of lipid-lowering treatment on circulating microparticles in patients with diabetes mellitus and chronic kidney disease. Nephrol Dial Transplant 31:944-952 
26. Faure V, Dou L, Sabatier F, Cerini C, Sampol J, Berland Y et al (2006) Elevation of circulating endothelial microparticles in patients with chronic renal failure. J Thromb Haemost 4(3):566-573

27. Chen YL, Chen $\mathrm{CH}$, Wallace CG, Wang HT, Yang CC, Yip HK (2015) Levels of circulating microparticles in patients with chronic cardiorenal disease. J Atherosclerosis Thrombosis 22(3):247-256

28. Lu GY, Xu RJ, Zhang SH, Qiao Q, Shen L, Li M et al (2015) Alteration of circulatory platelet microparticles and endothelial microparticles in patients with chronic kidney disease. Int J Clin Exp Med 8(9):16704-16708

29. Metzelaar MJ, Korteweg J, Sixma JJ, Nieuwenhuis HK (1991) Biochemical characterization of PECAM-1 (CD31 antigen) on human platelets. Thromb Haemost 66(6):700-707

30. Mei H, Campbell JM, Paddock CM, Lertkiatmongkol P, Mosesson MW, Albrecht R et al (2014) Regulation of endothelial cell barrier function by antibody-driven affinity modulation of platelet endothelial cell adhesion molecule-1 (PECAM-1). J Biol Chem 289(30):20836-20844

31. Privratsky JR, Newman PJ (2014) PECAM-1: regulator of endothelial junctional integrity. Cell Tissue Res 355(3):607-619

32. Kellermair J, Redwan B, Alias S, Jabkowski J, Panzenboeck A, Kellermair L et al (2013) Platelet endothelial cell adhesion molecule 1 deficiency misguides venous thrombus resolution. Blood 122(19):3376-3384

33. Wang JM, Huang YJ, Wang Y, Xu MG, Wang LC, Wang SM et al (2007) Increased circulating CD31+/CD42- microparticles are associated with impaired systemic artery elasticity in healthy subjects. Am J Hypertens 20(9):957-964

34. Bernal-Mizrachi L, Jy W, Jimenez JJ, Pastor J, Mauro LM, Horstman LL et al (2003) High levels of circulating endothelial microparticles in patients with acute coronary syndromes. Am Heart J 145:962-970

35. Werner N, Wassmann S, Ahlers P, Kosiol S, Nickenig G (2006) Circulating CD31+/annexin V+ apoptotic microparticles correlate with coronary endothelial function in patients with coronary artery disease. Arterioscl Thromb Vascular Biol 26(1):112-116

36. Sinning JM, Losch J, Walenta K, Böhm M, Nickenig G, Werner N (2011) Circulating CD31+/Annexin V+ microparticles correlate with cardiovascular outcomes. Eur Heart J 32:2034-2041

37. Ederhy S, Di Angelantonio E, Mallat Z, Hugel B, Janower S, Meuleman $C$ et al (2007) Levels of circulating procoagulant microparticles in nonvalvular atrial fibrillation. Am $\mathrm{J}$ Cardiol 100:989-994

38. Dursun I, Yel S, Unsur E (2015) Dynamics of circulating microparticles in chronic kidney disease and transplantation: is it really reliable marker?. World J Transplant 5:267-275

39. Nadar SK, Blann AD, Kamath S, Beevers DG, Lip GY (2004) Platelet indexes in relation to target organ damage in high-risk hypertensive patients: a sub-study of the Anglo-Scandinavian Cardiac Outcomes Trial (ASCOT). J Am Coll Cardiol 44(2):415-422

40. Caine GJ, Blann AD (2003) Soluble P-selectin should be measured in citrated plasma, not in serum. Br J Haematol 121(3):530-532 